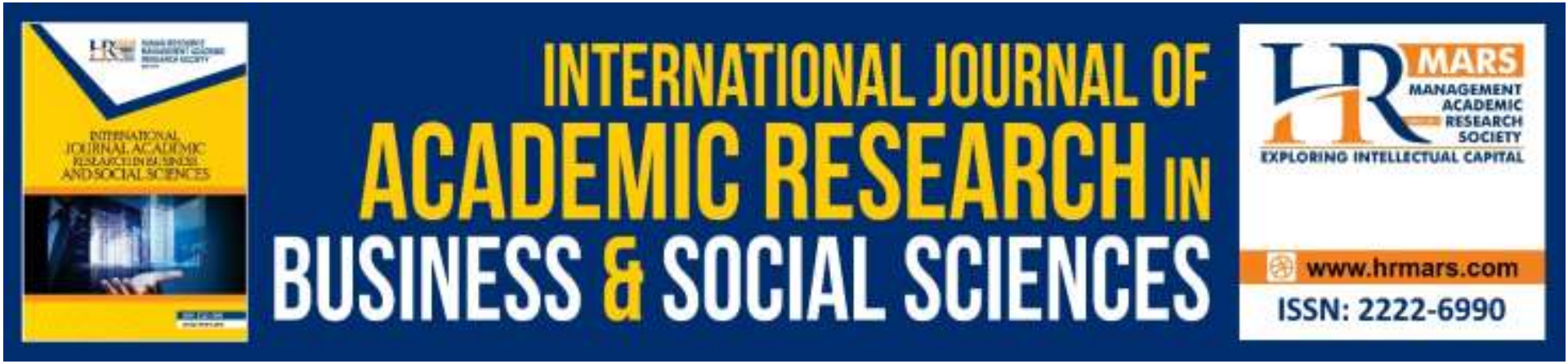

\title{
Influence of Socializing Agents on Children Involvement in Family Buying Decision Process
}

\author{
Sohail Ayaz Muhammad, Zermina Tasleem, Ahmad Salman
}

To Link this Article: http://dx.doi.org/10.6007/IJARBSS/v9-i9/6381

DOI: $10.6007 /$ IJARBSS/v9-i9/6381

Received: 10 July 2019, Revised: 12 August 2019, Accepted: 30 August 2019

Published Online: 22 September 2019

In-Text Citation: (Muhammad, Tasleem, \& Salman, 2019)

To Cite this Article: Muhammad, S. A., Tasleem, Z., \& Salman, A. (2019). Influence of Socializing Agents on Children Involvement in Family Buying Decision Process. International Journal of Academic Research in Business and Social Sciences, 9(9), 912-925.

Copyright: (C) 2019 The Author(s)

Published by Human Resource Management Academic Research Society (www.hrmars.com)

This article is published under the Creative Commons Attribution (CC BY 4.0) license. Anyone may reproduce, distribute, translate and create derivative works of this article (for both commercial and non-commercial purposes), subject to full attribution to the original publication and authors. The full terms of this license may be seen at: http://creativecommons.org/licences/by/4.0/legalcode

\section{Vol. 9, No. 9, 2019, Pg. 912 - 925}

Full Terms \& Conditions of access and use can be found at http://hrmars.com/index.php/pages/detail/publication-ethics 


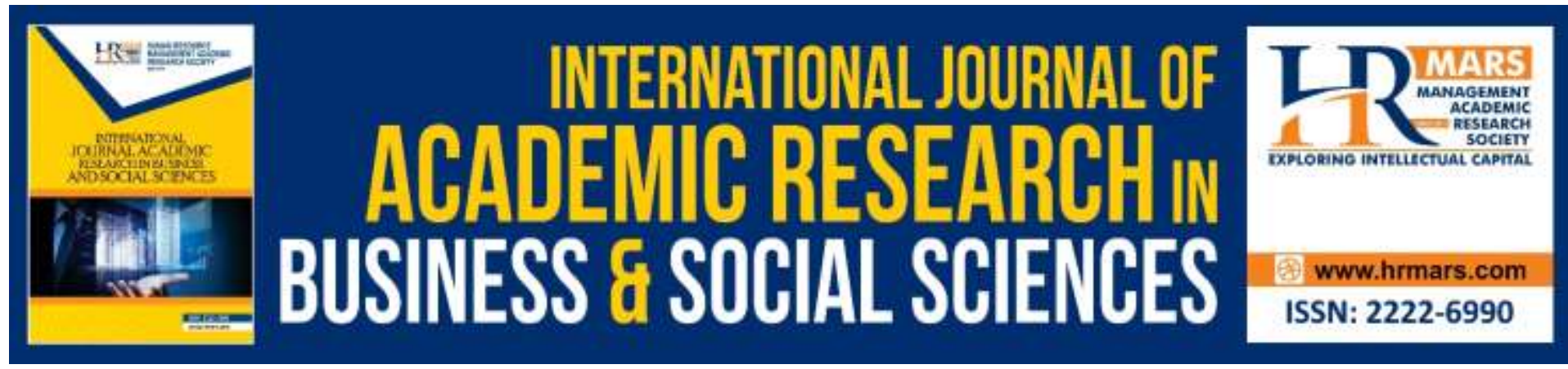

\title{
Influence of Socializing Agents on Children Involvement in Family Buying Decision Process
}

\author{
Sohail Ayaz Muhammad ${ }^{1}$, Zermina Tasleem², Ahmad Salman ${ }^{3}$ \\ ${ }^{1,3}$ Phd Scholar, University Sains Malaysia, Penang, Malaysia, ${ }^{2}$ Phd Scholar University Utara \\ Malaysia, Sintok, Malaysia
}

Email: rsohailayaz@gmail.com,zerminatasleem@gmail.com_ahmad.salman111@gmail.com

\begin{abstract}
Successful marketing can be achieved through a continuously focus on an appropriate consumer. Children are identified as active consumer and influencer in the modern market. This paper recognizes the emerging status of children as an influencer and has promoted researchers to conduct research in the developing country such as Pakistan on socializing agents that influence children on family buying decision. This research applied purposive sampling of 484 children (8-12-year-old age group) from major cities of the Punjab, Pakistan. A pilot study was conducted from 88 families to measure validity and reliability of the questionnaire. The results revealed that children provoked through parent-child relationship, pressure of the peer group, advertising, types of product and has a significant and positive influence on family purchase decisions in the Punjab, Pakistan. This research contributes with its understanding on contemporary influencer and consumer to support marketer with significant knowledge concerning to the influence of children on family purchase decision in Pakistan. It rouses marketers to be conscious that the children's purchasing power surge in future. This embraces noticeably more influence when it derives to purchasing decisions of family. Consequences of this research provide executives with significant information for modifying the effective strategies of marketing.
\end{abstract}

Keywords: Family Buying Process, Socializing Agent, Purchase Decision, Children

\section{Introduction}

Children are identified as a significant target market group and gain particular consideration from the marketing and practitioners as a consumer, buyers, customers, shoppers, spenders and influencer. They are dominant and involved in family buying decision process that show their significant position in the consumer market. Data from more than $50 \%$ of parents living in different Asian countries (Pakistan, Indonesia, Malaysia, Philippines, India and South Korea) suggested that children are important aspect of family buying decisions. It is also stated that "a child's demand" is a main cause behind the purchase of a product (Kaur \& Medury, 2010). Nowadays, it is trend that parents have fewer kids and they tend to purchase more goods for each kids. Also, rising ratio of one-parent families allows children to show their more interest in family decision making process. Moreover, parent mostly postponed kids until they are well 
established in their careers and in some cases both of parents are doing job. In all these scenarios, children might contribute highly in the buying decision. Thus, actual customer for the marketers in today's world is children.

The success of a marketer is based on considering the influence of children on family buying process. Until now, researchers are focusing on examining the influence of spouse on the decision-making process of family while studies do not concentrate on the role of children(Nørgaard \& Bruns $\varnothing$, 2011) Researcher in different countries dig out the study about the family buying process of product or brand choice but very few explored the socialization factors which stimulate the purchasing decisions. Numerous researchers focused on following industries, such as Marquis, (2004) used food take the sample from Canada, Nørgaard \& Bruns $\varnothing$ (2011) also done research on food in Denmark, study of Isin \& Alkibay, (2011) used products in Turkey and Chaudhary and Gupta (2012) focused on categorized and clustered products while conducting research in India. As significance, this research has measured the least examined socialization agents such as peer group, relationship of parent and children, types of product, and advertising. In the west and elsewhere, the influence of Children on family buying is growing continually. So far, with a limited exception, numbers of empirical researches were directed in the West and very few were known in the elsewhere about the influence of children (Shoham \& Dalakas, 2006). Thus, there is a requirement for further study regarding socialization agents that influences the children involvement on the decision about family purchase in developing courtiers especially in Pakistan. Hence, this research can fulfil this requirement. Furthermore, importance of children in decision making is neglected by the researchers, yet their importance is inevitable, thus it would be fascinating to see the result of research with children's role as decision makers.

Pakistan has observed notable changes in the past decade. The annual household income has risen by $124.3 \%$ from 2005 to 2016 . The average household size is 6.31 in 2016 slightly low from 2015 that is 6.35 (HIES 2015-2016). As per Census of Pakistan, 2016, $41 \%$ children constitute less than 14 years of age as per total population. This paper gain significance from Pakistan perspective as they are vital consumer segment both in volume and value. Pakistani society is very much different from the USA and European countries in term of family structure, culture, religious beliefs, and consumer behavior, that's why it is very essential to comprehend the influence of children in family purchase decision in Pakistan.

\section{Research Objective}

The objective of this research is to study the socializing agents that influence children to involve in the family buying decision process in the Punjab. The main objectives of this study include;

1. To identify the influence of children in family purchase decisions.

2. To study the role of children in family buying decisions with respect to the parent-child relationship, peer groups, types of product and advertising.

3. To examine the relationship between demographic variables and influence of children on purchase decision in the Punjab.

The study contributes empirically and furthers knowledge of consumer behaviors by which marketers can influence purchases related to children. This research will be useful for marketers to construct different policies which can amplify the service delivery mechanism. This research also helpful to the government while identifying the important aspects that formulate impact of children on the family buying decision process and should keep in view 
the certain facts while producing the media content, as they should formulate right policies in the favour to protect the children from bold media content.

This paper consists of four sections, including an introduction. Section 2 provides literature related to children influence in the family buying decision process and behaviors of the children and section 3 elaborate research methodologies. The section 4 explains the detailed results and analysis and finding is a considerable effort to pin down the generalization that could be helpful for future researches.

\section{Literature Review}

Previous researchers have identified that children were studied as a consumer in 1960 and it was only in 1970s that children were the main focus point for marketers. (Ward, 1974) stated the first definition of Consumer Socialization of children as "it is method through which children get attitudes, knowledge and skills related to their representation as consumers in the market". Moreover, recent revolution in social and demographic structures is strengthening the influence of children on family buying decisions. With the specified focus of the marketing agencies, the role of children as important consumers, decision maker for various products has become extremely significant. Children are decision maker, spender and purchaser for their own goods and also for family products (Nørgaard, Bruns, Christensen, \& Mikkelsen, 2007).

Additionally, different socialization agents were identified that were parent-child relationship, the pressure of the peer group, types of product, advertising, parent education, household income and family size. Parents normally assume as a primary responsible for teaching their children to refine their behavior as a consumer (Behavioral et al., 2016). The family is a primary socioeconomic unit that has an important role to persuade and influence consumer preferences of their children. Children and parents set up consumption priorities which help in deciding how to buy necessary items (Fan \& Li, 2010). Family members are thus highly significant in deciding the way products are acquired, consumed and influenced. The influence concept in the process of family decision-making is explained by (Nørgaard \& Bruns $\varnothing, 2011)$ as it is the transformation in the individuals' characters due to the interaction among children and their parents. The parent's response to the attempts of children during the process of family purchases is act as supports to the future behavior of children as a consumer. Some parents satisfy the requisitions of children and they elevate the children to focus on advertising and discuss the product most frequently. However, some parents deliberate the requests of children and improve their abilities and skills in choosing and understanding the information about the product (Fan \& Li, 2010). Thus, parents are the most significant agents of socialization and the changing in the children skills and behavior can easily explain the parent-child relationship.

In addition, peer groups are associated with the purchase decision making followed by children. Influence of peer group is shown in children decision about purchase while measuring brands, goods, and stores. Mostly, peer groups improve children sense of belonging by serving them and create an individuality distinct from parents (Opoku, 2012). Most of the scholars observed that peers are the important source which influences children consumer socialization (Gillani, 2012; Makgosa \& Mohube, 2007; Mokhtaran \& Assar, 2014; Valkenburg \& Cantor, 2001). Interaction of Peer also delivers the kid with non-rational bases of consumer socialization (Makgosa \& Mohube, 2007). Mokhtaran, \& Assar (2014) observed that impact of friends is high on some of goods such as public luxuries but less on private 
necessities. This concerned an influence of peer group is a considerate of children consumption representation. Most friends are expected to help kids in measuring brands, goods, and stores. Friends improve a kid sense of belonging by serving them and create an individuality distinct from parents (Gillani, 2012). Research also depicted that preadolescents are more dependent on their parents while, middle or late youth have more self-identity and sense of maturity which reduce vulnerability to peer pressure (Valkenburg \& Cantor, 2001). Peer highly influence the children when they are adolescent as the age of 14 years and it slowly steeps down through late and middle adolescence (Steinberg, 2001).

Furthermore, children used the information that they get from advertisement in their efforts to influence decisions of family (Bartol \& Bartol, 2017). The advertisement contains a high degree of information which presents the consumer with product features or attributes that make a good attitude and is used for the rational brand preference (Gbadamosi, Hinson, Tukamushaba, \& Ingunjiri, 2012). The advertisement catches or grabs the attention and gives awareness to the individuals. Thus, advertisements contain a lot of information regarding products and services (Sheehan, 2013). Advertising is a planned applied communication that gives both verbal and non-verbal components which fill definite time and space to examine by a sponsor. Furthermore, research on children about the source which give information about the new product in China explained that TV is a main source of information for children to learn about the new goods and perceived significance of TV increases as the age of the children increase (Hameed, Waqas, Aslam, Bilal, \& Umair, 2014). Children watched more than the programs which are directed toward their age groups. Their consumption and advertising experience cover goods and services designed obviously for them. Thus, advertisement on the TV has an iconic importance as a curiously visible factor that focuses on children (O'Sullivan, 2005).

Children play a prominent role in choice of product type. Most of the goods are always selected by children for example their toys and clothes but it has been also viewed that they also interfere in the decision of parental and family product choice. The influencing power of children is very high (Slatcher \& Trentacosta, 2012). (Martensen \& Gronholdt, 2008) explored that children act as an initial influencer. It is also explicit that children influence the decisions about the vacations, cable TV subscriptions, eating out, movie attendance and family past time recreational activities. In these activities, children showed their influence lesser as compare to product choice. The children in the buying of products like children's wear, toys and cereals are more dominant in Western countries (Flurry \& Veeck, 2009). When families are making a decision about vacations, to watch movies and to eat out than children also put their suggestions (Martensen \& Gronholdt, 2008). Thus, children proved their key involvement in the consumer market by influencing the buying of goods either for themselves or for family. The decisions about buying are influenced by family structure, peer group and buying habits (Chaudhary \& Gupta, 2012; Kotler, 2009). Thus, it is very important for a researcher to explored factors that influences the children to put their impact on the decision about family purchase.

It is also observed that family demographics is a vital element of socialization for children and it has been measured on favorable premise. Family size play important role in child development, which leads a child to learn behavior and attitude ((Mulligan \& Carpenter, 2010; Sargent, 2001) Family size unfold the set of share values which enable families in providing primary resource and economic support and feelings of value, love and companionship, competence. Thus, families should be observed as a dynamic social set which includes parents 
and the children teach, learn and numeral factors that outline the communication environment (Nach \& Lejeune, 2009). De Pelsmacker, Geuens, and Anckaert (2002) described that the more modern forms of the family like single-parent families had a small influence on the impact of children in numerous decision-making conditions. Age of the children has been one fluctuating factor in this research. More scholars have described the behavior and attitude of adolescent children (Higgs, 2015; Pedersen, Grønhøj, \& Thøgersen, 2015). Moreover, Burgess and Steenkamp (2006) reveals that now it is a time for marketing revitalization. The present researches undergoes with the constraint to direct in high income countries. Thus, there is a need to research the new trend in market by considering children as a consumer that showed significant influence in family buying decision process.

\section{Conceptual Framework}

This framework in figure 1 describe how children influences the buying of family and it relationship with different socialization agents such as parent-child relationship, the pressure of peer group, advertising, types of product. Parent education, family structure and family income are considered as a controlling variable.

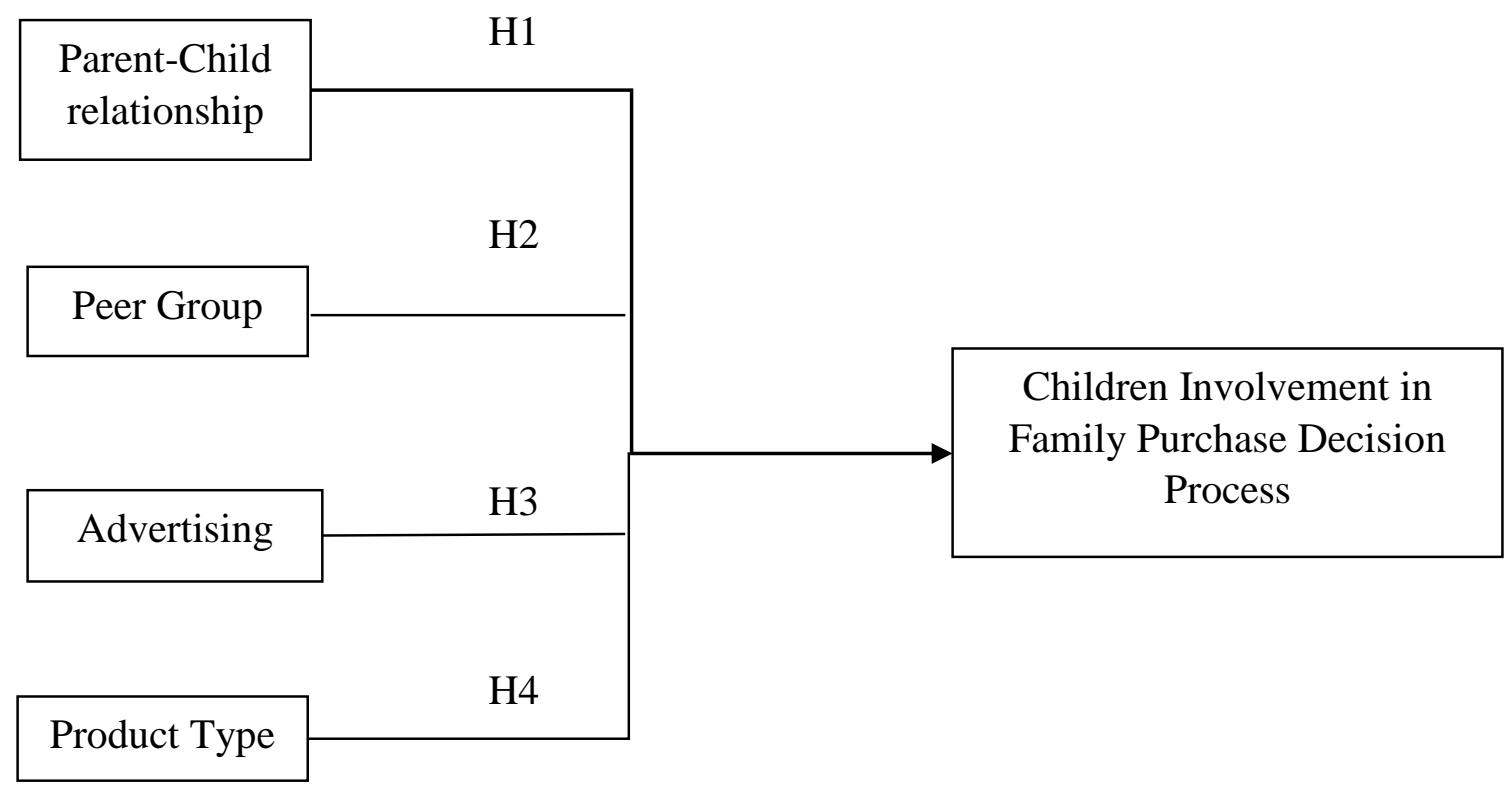

\section{Figure 1: Conceptual framework \\ Research Methodology}

Researcher used exploratory research as well as conclusive research design. The exploratory research focused to determine the phenomena which cannot be reconnoitered by the conclusive design, whereas conclusive study design is the descriptive methods and causal study that is deliberate to describe definite phenomena and notice detailed relations between the essentials of the research (Malhotra \& Birks, 2007). Further, a survey technique was used to test the independent variables which were peer group, the relationship among children and parent, types of product and advertisement that influence children to involve in family buying decision.

This research focused on a whole group that was known as population and sample consisted of the population top five major cities of Punjab are Lahore, Faisalabad Rawalpindi, Gujranwala, and Multan. Researcher was targeting the children of age $8-12$ years in the 
Punjab, Pakistan and used parents and take children as objects of this study. Their practices about consumption were viewed by the parents. The sampling frame was households which had children of age 8-12 the five major cities of Punjab such as, Lahore, Faisalabad Rawalpindi, Gujranwala, and Multan.

Researcher employed the mixed sampling design, the cluster sampling used and the major cities were selected for data collection on the basis of purposive sampling which represented the population of Punjab, Pakistan, which was divided into 5 clusters. These clusters form equal percentages which were linked to the children and represented them in the families. After review of selections of sample size and their limitations, the questionnaire comprised of 45 items ( 8 items of demography) from which the optimal sample is selected, that is of 315 . Due to Purposive sampling, scholar had opportunities to select families which had 8-12 years old children from different families with different age distribution. Furthermore, sample was divided between the cities proportionately and final sample size was 484 .

The standardized semi-structured questionnaires were used in the field survey for data collection and each item was designed to specify the research question, objective, and hypothesis. The questionnaire was adapted from the researches of Kiriinya (2017), Chaudhary and Gupta (2012) and Kiriinya, Bwisa, and Orwa (2014) which had 45 items that described the variable use in survey. The different responses were determined on a five-point scale. Fivepoint scales were used for parent questionnaire. Scaling defines the assigning procedure of numbers to several degrees of attitude, concepts and another opinion. The reason for selecting the Likert scale was that this scale measured as the easiest one to fill out (Van Laerhoven, Van Der Zaag-Loonen, \& Derkx, 2004). The technique of Likert scale had a sequence of a statement due to which one participant can use a scale of conceivable answers. strongly disagree (1), disagree (2), Neutral (3), agree (4), Strongly agree (5), and the score can be vice-versa.

There was a need to collect the responses from the parents. The parents who have children of 8-12 years old in Punjab, Pakistan were considered as the unit of analysis for the research. Also, the response from every parent was measured as a separate source of data in the research.

The Likert scale statement was used that make a correlation between the processes or real objects and the concepts of abstract of the theory that is established as the measures of psychometric. The psychometric measures include the process of family purchase decision that is dependent variable, peer group, parent-child relationship, product types and advertising that are independent variables. It also includes Likert scale of five points (strongly disagree $=1$, disagree $=2$, Neutral $=3$, agree $=4$, strongly agree $=5$ ) for confirming statements. The mean is also measured as an average of 5 items measured by the perceived influence on buying decisions.

The raw collected data needs to be changed into authentic information that will further answer the desired research questions. Collected data was refined, modified and then coded before it is used for data analysis. All the data was coded and then entered into the SPSS, after that data was analysed to test the hypotheses. After getting the correlations dimensions, next stage was to analyze the association through regression. The relationship between the variables is illustrates through following models;

Model $1 \quad \mathrm{PD}=\alpha+\beta 1 \mathrm{PCR}+\beta 2 \mathrm{Edu}+\beta 3 \mathrm{ICOM}+\beta 14$ FSTR

Model $2 \quad P D=\alpha+\beta 1 P G+\beta 2 E d u+\beta 3 I C O M+\beta 14$ FSTR

Model $3 \quad P D=\alpha+\beta 1 A D+\beta 2 E d u+\beta 3 I C O M+\beta 14$ FSTR 
Model $4 \quad P D=\alpha+\beta 1 P T+\beta 2$ Edu $+\beta 3 I C O M+\beta 14$ FSTR

Where; $P D=$ Purchase Decision; $P C R=$ Parent-Child relationship; $P G=$ Peer group; $P T=$ Product type; $E d u=$ parent Education; $A D=$ Advertisement; $I C O M=$ Family income and $F S T=$ family structure

\section{Results and Discussions}

The general descriptive analysis included relationship of the respondent with the child, family type, family structure, salary and education of the respondents.

Table 01: Frequencies and Percentages of Respondent

\begin{tabular}{llll}
\hline Demography & Indicator & Frequency & Percentage \\
\hline Relationship & Father & 281 & 58.1 \\
& Mother & 196 & 40.5 \\
& Guardian & 6 & 1.2 \\
Family type & Others Specify & 1 & .2 .00 \\
& Both parents & 424 & 87.6 \\
& Single parent & 57 & 11.8 \\
Family structure & Guardian & 3 & .6 \\
Income level (Rs) & Single child & 201 & 41.5 \\
& With siblings & 283 & 58.5 \\
& Less than 30,000 & 242 & 50.0 \\
& 30,001-60,000 & 229 & 47.3 \\
Education & 60,001- Above & 13 & 2.7 \\
& University & 66 & 13.6 \\
& College & 218 & 45.0 \\
& Secondary & 180 & 37.2 \\
& Primary & 20 & 4.1 \\
\hline
\end{tabular}

Table 02: Descriptive Statistics

\begin{tabular}{llll}
\hline Construct & N & Mean & Std. Deviation \\
\hline Parent Child Relationship & 484 & 3.786 & 0.533 \\
Peer Group & 484 & 3.656 & 0.433 \\
Advertisement & 484 & 3.826 & 0.696 \\
Product type & 484 & 3.701 & 0.633 \\
Purchase decision process & 484 & 3.946 & 0.366 \\
\hline
\end{tabular}

Results indicated that mean of all constructs in this research lies in between 1.13 to 3.96. Thus, these values are found in acceptable range and they all are above average values. Mean of independent variables: Parent-Child relationship was $3.786(S . D=0.533)$, Peer Group was 3.656 (S. $D=0.433$ ), Advertisement was 3.826 (S. $D=0.696$, Product type was 3.701(S. $D=$ 0.633 ) and dependent variable purchase decision process had $3.946(S . D=0.366$ ) mean value. The values of standard deviation for all the constructs lie in the range of 0.355 to 0.928 that is also in the tolerance range. It can be obviously recognized that all the variables have a reasonable and adequate implementation level.

The correlation results indicate that children influence on purchase decisions of the family were determined to be positively and significantly correlated with a value of $R=0.406$ for the 
parent-child relationship, $\mathrm{R}=0.367$ for the peer group, $\mathrm{R}=0.361$ for advertising and $\mathrm{R}=0.450$ for types of product at $p=0.000$ respectively. The results of correlation are shown in table 03 .

Table 03: Pearson Correlation Results

\begin{tabular}{llllll}
\hline & PCA & PGA & ADA & PTA & PD \\
\hline PCA & 1 & & & & \\
PGA & $0.434^{* *}$ & 1 & & & \\
ADA & $0.376^{* *}$ & $0.331^{* *}$ & 1 & & \\
PTA & $0.591^{* *}$ & $0.391^{* *}$ & $0.357^{* *}$ & 1 & \\
PD & $0.406^{* *}$ & $0.367^{* *}$ & $0.361^{* *}$ & $0.450^{* *}$ & 1 \\
\hline
\end{tabular}

Note: PCA=Purchase decision; PGA= Peer Group; ADA= Advertising; PTA= Product Types;

$* * *, * * \& *$ represent significance at $.01, .05$, and .10 level, respectively.

In this research, multiple regression analysis is used to measure the association among variables. The main reason to test hypothesis is to check the accuracy of research hypotheses that why the scholar gathered a data from a sample (Kothari, 2004). To test $\mathrm{H} 1$, the researcher conducted regression analysis to measure the relationship among children influence on purchase decisions process of family and parent-children relationship.

Table 04: Regression Results of family Purchasing Decision Model 1, II, III \&IV

\begin{tabular}{|c|c|c|c|c|}
\hline & Model-1 & Model-1I & Model-1II & Model-1V \\
\hline \multirow[t]{2}{*}{ Constant } & $3.073 * * *$ & $3.283 * * *$ & $3.354 * * *$ & $3.140 * * *$ \\
\hline & $(0.146)$ & $(0.155)$ & $(0.122)$ & $(0.125)$ \\
\hline \multirow[t]{2}{*}{ Parent-child Relationship } & $0.202 * * *$ & & & \\
\hline & $(0.030)$ & & & \\
\hline \multirow[t]{2}{*}{ Peer group } & & $0.175^{* * *}$ & & \\
\hline & & $(0.038)$ & & \\
\hline \multirow[t]{2}{*}{ Advertisement } & & & $0.137 * * *$ & $0.137 * * *$ \\
\hline & & & $(0.023)$ & $(0.023)$ \\
\hline \multirow[t]{2}{*}{ Product type } & & & & $0.194 * * *$ \\
\hline & & & & $(0.025)$ \\
\hline \multirow[t]{2}{*}{ Family Education } & 0.025 & 0.008 & 0.017 & 0.019 \\
\hline & $(0.021)$ & $(0.022)$ & $(0.021)$ & $(0.021)$ \\
\hline \multirow[t]{2}{*}{ Family structure } & -0.007 & -0.044 & -0.021 & -0.011 \\
\hline & $(0.032)$ & $(0.033)$ & $(0.033)$ & $(0.032)$ \\
\hline \multirow[t]{2}{*}{ Family Income } & .039 & 0.045 & 0.040 & 0.039* \\
\hline & $(0.029)$ & $(0.030)$ & $(0.021)$ & $(0.029)$ \\
\hline R2 & $9.3 \%$ & $5 \%$ & $7.5 \%$ & $12 \%$ \\
\hline $\mathrm{F}$ & $12.34 * * *$ & $6.264 * * *$ & $9.778 * * *$ & $16.342 * *$ \\
\hline
\end{tabular}

Note: PCA=Purchase decision; PGA $=$ Peer Group; ADA $=$ Advertising; PTA= Product Types; $* * *$ Significance at $1 \%^{* * *}, * *$ at $5 \%$ and ${ }^{*}$ at $10 \%$ level of significance, Standard error in parenthesis. Dependent variable: Family Purchase Decision

The value of $R^{2}$ is $9.3 \%$ and F-test value is 12.34 , which indicated that there is a significant link between parent-child relationships on the children to influence the decisions process of family buying in the Punjab. The results of ANOVA in table 04 showed an association among parent-child relationships on children to influence the process of family buying decisions. There is a prominent influence of Parent-child relationships on children to influence the process of family buying decisions in the Punjabis. It was also found that parent-child relationships have significant influence children to involve in the process of family buying 
decisions ( $\mathrm{P}$-value<0.05). The beta coefficient and t-test were also computed to test the $\mathrm{H} 1$ and $\beta$ value indicated that the relationship among variables was statistically significant ( $P$ value $<0.05)$, thus, the $\mathrm{H} 1$ was accepted. Therefore, a positive relationship is proved from these values. This means that increase in a relationship of parent-child increases children influence on purchase decisions of family. Scholar Wimalasiri (2004) determined that the purchase decisions of family become high as the parents permitted numerous tactics that children used to influence them. This improves family self-reliance and participation. Moreover, results shown in table indicated that the significance value of family structure, education, family income (controlling variables) was $0.841,0.237$ and 0.181 respectively.

These results indicate that there is a significant influence of parent-child relationships on children to involve in family purchase decisions in Punjab. It is also concluded that purchase decision-making of family is a combined process where parents as well as children influence decisions and contribute and bring out numerous responsibilities. The finding of this research supported the finding of Nørgaard and Brunsø (2011).

These results also reveal that children would become an early experience in emerging product consumer behaviours. The children apply tactics to influence their parents, on what kid potentials in return to a favour of buying appeal. The consequences of this research are also in line with the findings of Eekelaar (2017) who revealed that children have an extended range of approaches for influencing purchase decisions of family. The research definite a partiality for influential approaches that children of 8-14 years old used; specifically, stating their ideas, maintaining their preferences or emotional and begging approaches i.e. asking frequently for a goods or being affectionate and nice. Present study results supported the finding of Kiriinya (2017)and also in line with Kiriinya et al. (2014) where he revealed that children derived with ingratiating strategies such as the children are in search of making the mood of their parent good or think positively of her or him before telling them to fulfil their buying request.

The $\mathrm{H} 2$ was tested and outcomes show that the relationship among variables was statistically significant as the t-value was 4.602. Thus, the hypothesis 2 has been approved (Pvalue $=0.000$ ). Therefore, a positive relationship is proved by these values. This means that increase influence of the peer group on children increases the purchase decisions of family. According to these findings, it is stated that there is a significant influence of peer group on Children to involve in process of family buying decisions in Punjab. The value of $F$ is 3.84 that confirmed a significance relationship between peer group and children influence on family purchase decision. Thus, it is determined that peer group has a linear relationship with the children influence on process of family buying decisions in Punjab. Moreover, education, family structure and family income are used as control variables and results indicate the significance value $0.706,0.233$ and 0.133 respectively. The value of $R^{2}$ for a peer group in this research is not high (0.134) that shows that peer group influences partially on children to involve in purchase decision of family. The results for $\mathrm{H} 2$ supported the current meanings of influence distinctive among passive and active influence (Chaudhary \& Gupta, 2012). Further, it is found that the pressure of peer group influences children positively to involve in the purchase decisions of family. These results are in line with finding of Batounis-Ronner, Hunt, and Mallalieu (2007) that peer groups influence apply on the products and brands types while purchases of an individual, is varied, with peers working out on a feeling that a buyer would improve individual image with the group and permitting individuals preference of the group to affect individual decision to buy a goods. Outcomes also supported the finding of Kiriinya (2017)and Opoku (2012) that learning of children about expressive fundamentals of 
consumption, such as social motivations and materialistic values and effective consumption such as moods and consumption styles are done from their friends.

To test H3: There is a significant influence of advertising on children in the process of family buying decisions in Punjab was also proved by the results of ANOVA. It was also found that advertising have a significant influence on children to involve in the process of family buying decisions ( $p$-value is less than 0.05). Thus, hypothesis H3 was accepted and a positive relationship is proved by these values. The results also indicate that significance value of education, family structure and family income was $0.425,0.512$, and 0.171 respectively. Results of H3 supported the research of Percy (2016). Results are consistent with literature and also supported the finding of Fan and Li (2010) that resulted that children interrelate frequently with most advertising media among which T.V is most vital media. Results of this research also supported the finding of (Kiriinya, 2017; Kiriinya et al., 2014)

$\mathrm{H} 4$ was tested through the values of $\beta$ coefficient and $t$. association among variables was statistically significant as $t$-value was 25.07 that is greater that critical $t=1.96$. Thus, hypothesis $\mathrm{H} 4$ was accepted and confirmed that increase in types of product increases influence of children on the family purchase decisions. The value of R-square $(0.12)$ reveals a moderate relationship among types of product influence children to involve in the process of family buying decisions in Punjab. Furthermore, results indicated that significance value of education, family structure and family income was $0.359,0.730$, and 0.168 respectively. Moreover, results confirmed a significant positive association between types of product and children influence on family buying decisions and results showed that influence of children vary across various types of product. These results are supported with research of Chaudhary and Gupta (2012) that there is an influencing power in the children for almost all categories of product either the product is for the use of family or for child's own. The results also supported the finding of Kiriinya (2017) that mostly child decisions depend on the predetermined limitations recognized by the parents. Ming Wut and Chou (2009) results also supported this research that influence of children is more in the choice-making phase of the process of decision making and the final decision are still control by the parents.

Table 5: Summary of Outcomes for All the Hypotheses

\begin{tabular}{|c|c|c|c|c|}
\hline Hy & Statement & Sign & Sig & Decision \\
\hline $\mathrm{H} 1$ & $\begin{array}{l}\text { There is a significant influence of Parent-child } \\
\text { relationships on children involvement in the } \\
\text { process of family buying decisions in Punjab. }\end{array}$ & + & significant & Accepted \\
\hline $\mathrm{H} 2$ & $\begin{array}{l}\text { There is significant influence of peer group on } \\
\text { children involvement in the process of family } \\
\text { buying decisions in Punjab. }\end{array}$ & + & significant & Accepted \\
\hline H3 & $\begin{array}{l}\text { There is a significant influence of advertising on } \\
\text { children involvement in the process of family } \\
\text { buying decisions in Punjab. }\end{array}$ & + & significant & Accepted \\
\hline $\mathrm{H} 4$ & $\begin{array}{l}\text { There is a significant influence of types of product } \\
\text { on children involvement in the process of family } \\
\text { buying decisions in the Punjab. }\end{array}$ & + & significant & Accepted \\
\hline
\end{tabular}




\section{Conclusions}

This research concluded that children influencing patterns depends upon various social entities which foster their influences towards purchasing attitude of family. It is found that the parents seem to be the main influential agent from where the children learn their buying behaviour. Findings of this research also exposed that parent-child relationship significantly influenced children to involve in purchase decisions of a family in Punjab. Mechanism of the purchase decision for a family is a collective procedure where both parents and children contribute and carry out several household tasks and controls decisions. Thus, it brings light to an important point that parent-child relationship partially influences children to involve in the purchase decision. Additionally, findings reveals that peer group has momentous influence on children to involve in the family purchase decision. Influences of children for goods are similar as they possessed by their peer groups. This research come up with a view that communication becomes effective through advertising that directed children to involve in the process of family buying decisions in Punjab. Findings also showed that perceptions of children were influenced by the exposure of watching an advertisement; a consideration which means that children identify the advertisement and responsiveness when there is some humour in the advertisement; and retention that stays or keeps in the children mind. Moreover, result of this research unveiled that types of product narrate children contribution in the process of family buying decisions. Types of product have a dominant impact on children to involve in the process of family buying decisions in Punjab. Thus, children showed great influence on the family buying decision about products whether it is for the use of their family or for own such as clothes, snacks, toys, etc. Results of this study contributed to the prevailing knowledge in literature of customer roles in purchase decisions of family. Research laid its focus on the equal participation of consumer role and deliberates children as being equal contributors in the process of decision making for a family just as parents. The consequences of this research provide the executives with significant information for modifying the effective strategies of marketing.

\section{Recommendations}

As a recommendation for future research, there is a requirement to carry out an analogous study on the influence of children to purchase decisions of a family in Pakistan although using both children and guardians/parents in order to create whether the two results would approve for simplification. Additionally, as Pakistan is steadily and slowly moving towards healthier economic conditions and towards the varying routine, the need to research about the influence of children will rise as a notable concern for the marketers. Thus, an attempt to generate a strong knowledge base, it would be beneficial that the future scholars deeply investigate the influence of children in respect to the family purchase decision through mixed method or qualitative studies. Additional research involves in-depth interviews with marketing academicians and marketers would further strengthen this area of study.

\section{References}

Bartol, C. R., \& Bartol, A. M. (2017). Introduction to forensic psychology: Research and application: Sage Publications.

Batounis-Ronner, C., Hunt, J. B., \& Mallalieu, L. (2007). Sibling effects on preteen children's perceived influence in purchase decisions. Young Consumers, 8(4), 231-243. 
Burgess, S. M., \& Steenkamp, J.-B. E. (2006). Marketing renaissance: How research in emerging markets advances marketing science and practice. International Journal of Research in Marketing, 23(4), 337-356.

Chaudhary, M., \& Gupta, A. (2012). Children's influence in family buying process in India. Young Consumers, 13(2), 161-175.

Pelsmacker, D. P., Geuens, M., \& Anckaert, P. (2002). Media context and advertising effectiveness: The role of context appreciation and context/ad similarity. Journal of Advertising, 31(2), 49-61.

Eekelaar, J. (2017). The interests of the child and the child's wishes: The role of dynamic selfdeterminism Children's Rights (pp. 129-148): Routledge.

Fan, Y., \& Li, Y. (2010). Children's buying behaviour in China: A study of their information sources. Marketing Intelligence \& Planning, 28(2), 170-187.

Flurry, L. A., \& Veeck, A. (2009). Children's relative influence in family decision making in urban China. Journal of Macromarketing, 29(2), 145-159.

Gbadamosi, A., Hinson, R. E., Tukamushaba, E. K., \& Ingunjiri, I. (2012). Children's attitudinal reactions to TV advertisements: the African experience. International Journal of Market Research, 54(4), 543-566.

Gillani, F. (2012). Impact of peer pressure and store atmosphere on purchase intention: An empirical study on the youngsters in Pakistan. International Journal of academic research in Business and Social Sciences, 2(7), 323.

Hameed, A., Waqas, A., Aslam, M. N., Bilal, M., \& Umair, M. (2014). Impact of TV advertisement on children buying behavior. International Journal of Humanities and Social Science, 4(2), 246-261.

Higgs, S. (2015). Social norms and their influence on eating behaviours. Appetite, 86, 38-44.

Isin, F. B., \& Alkibay, S. (2011). Influence of children on purchasing decisions of well-to-do families. Young Consumers: Insight and Ideas for Responsible Marketers, 12(1), 39-52.

Kaur, A., \& Medury, Y. (2010). Children's influence on family purchases: some new insights. Paper presented at the Global Marketing Conference, September.

Kiriinya, S. N. (2017). Influence of Advertising to Children on Family Purchase Decisions of Households in Kenya. Frontiers of Marketing Research (ISSN-2456-3919), 2(1).

Kiriinya, S. N., Bwisa, H., \& Orwa, G. (2014). CHILDREN'S INFLUENCE ON FAMILY PURCHASE DECISIONS IN KENYA. International Journal of Advanced Research in Management and Social Sciences, 3(7), 59-80.

Kothari, C. R. (2004). Research methodology: Methods and techniques: New Age International.

Kotler, P. (2009). Marketing management: A south Asian perspective: Pearson Education India.

Kümpel Nørgaard, M., Bruns, K., Haudrup Christensen, P., \& Romero Mikkelsen, M. (2007). Children's influence on and participation in the family decision process during food buying. Young Consumers, 8(3), 197-216.

Makgosa, R., \& Mohube, K. (2007). Peer influence on young adults' products purchase decisions.

Malhotra, N., \& Birks, D. (2007). Marketing Research: an applied approach: 3rd European Edition: Pearson education.

Marquis, M. (2004). Strategies for influencing parental decisions on food purchasing. Journal of Consumer Marketing, 21(2), 134-143. 
Martensen, A., \& Gronholdt, L. (2008). Children's influence on family decision making. Innovative Marketing, 4(4), 14-22.

Ming Wut, T., \& Chou, T.-J. (2009). Children's influences on family decision making in Hong Kong. Young Consumers, 10(2), 146-156.

Mokhtaran, M., \& Assar, S. S. (2014). Peer influence and purchase of different products: evidence from Iran young adults. Advances in Environmental Biology, 1931-1938.

Mulligan, E. A., \& Carpenter, B. D. (2010). Later-life family assessment. Clinical Gerontologist, 34(1), 4-20.

Nach, H., \& Lejeune, A. (2009). A model of individual coping with information technology challenges to identity. AMCIS 2009 Proceedings, 174.

Nørgaard, M. K., \& Bruns $\varnothing$, K. (2011). Family conflicts and conflict resolution regarding food choices. Journal of Consumer Behaviour, 10(3), 141-151.

O'Sullivan, T. (2005). Advertising and children: what do the kids think? Qualitative Market Research: An International Journal, 8(4), 371-384.

of Behavioral, D., Sciences, S., Breiner, H., Ford, M., Gadsden, V. L., National Academies of Sciences, E., \& Medicine. (2016). Parenting Knowledge, Attitudes, and Practices.

Opoku, R. (2012). Young Saudi adults and peer group purchase influence: a preliminary investigation. Young Consumers, 13(2), 176-187.

Pedersen, S., Grønhøj, A., \& Thøgersen, J. (2015). Following family or friends. Social norms in adolescent healthy eating. Appetite, 86, 54-60.

Percy, L. (2016). Strategic advertising management: Oxford University Press.

Sargent, J. (2001). Variations in family composition: implications for family therapy. Child and Adolescent Psychiatric Clinics, 10(3), 577-599.

Sheehan, K. B. (2013). Controversies in contemporary advertising: Sage Publications.

Shoham, A., \& Dalakas, V. (2006). How our adolescent children influence us as parents to yield to their purchase requests. Journal of Consumer Marketing, 23(6), 344-350.

Slatcher, R. B., \& Trentacosta, C. J. (2012). Influences of parent and child negative emotionality on young children's everyday behaviors. Emotion, 12(5), 932.

Steinberg, L. (2001). We know some things: Parent-adolescent relationships in retrospect and prospect. Journal of research on adolescence, 11(1), 1-19.

Valkenburg, P. M., \& Cantor, J. (2001). The development of a child into a consumer. Journal of Applied Developmental Psychology, 22(1), 61-72.

Laerhoven, V. H., Zaag-Loonen, V. D. H., \& Derkx, B. H. (2004). A comparison of Likert scale and visual analogue scales as response options in children's questionnaires. Acta paediatrica, 93(6), 830-835.

Ward, S. (1974). Consumer socialization. Journal of consumer research, 1(2), 1-14.

Wimalasiri, J. S. (2004). A cross-national study on children's purchasing behavior and parental response. Journal of Consumer Marketing, 21(4), 274-284.

\section{Corresponding Author}

Sohail Ayaz Muhammad

Email: rsohailayaz@gmail.com 